\title{
SEASONAL CHANGES IN FREQUENCY OF THE "YELLOW" MORPH OF THE ISOPOD, SPHAEROMA RUGICAUDA
}

\author{
D. J. HEATH* \\ Department of Zoology, University of Edinburgh
}

Received 31.viii.73

\begin{abstract}
SUMmary
The estuarine isopod Sphaeroma rugicauda is polymorphic for body colour. The frequency of one morph, Yellow, was studied over a 3-year period in a population in the Tyne estuary, East Lothian, Scotland. The Yellow form is controlled by a single dominant gene, the recessive condition being represented by the morph Grey, which is at a frequency of around 0.60 in the population studied.

An initial inspection of the frequency data suggested that Yellow declined in frequency over the October-January period and increased in frequency over the January-March period. These two periods were characterised by water temperatures estimated to be $12^{\circ}-5^{\circ} \mathrm{C}$. and below $5^{\circ} \mathrm{C}$. respectively, and salinities were generally low over both periods.

Experimental comparisons of the survival of Yellow and Non-Yellow showed that at $10^{\circ} \mathrm{C}$. and low salinity, Non-Yellow survived better and that at $0^{\circ} \mathrm{C}$. and low salinity, Yellow survived better than Non-Yellow.

The frequency data were then re-analysed, after dividing them up on the basis of the experimental temperatures. In 2 years Yellow showed a significant decline in frequency over the October-January period. In only 1 year, characterised by exceptional mildness did Yellow increase in frequency over the January-March period. In the other 2 years, Yellow did not increase in frequency over this period but did seem to increase in frequency once the temperatures rose above $5^{\circ} \mathrm{C}$. A possible explanation of this reversal in survival is put forward, based on differences in growth rate between the two morphs.

Natural selection provides the most likely explanation for the observed frequency changes. It seems probable that the two morphs are maintained in the population by the action of these two or more opposing selective forces, alternately favouring the Non-Yellow and Yellow morphs.
\end{abstract}

\section{Introduction}

The study of seasonal variations in the frequencies of genotypes in natural populations can reveal the action and the strength of natural selection (Dobzhansky, 1947; Strickberger and Wills, 1966; Bishop, 1969).

West (1964) produced evidence for temporal changes in the frequencies of two morphs of the isopod Sphaeroma rugicauda and suggested that natural selection was the cause.

Bishop (1969) found seasonal changes in the frequency of the Yellow morph of $S$. rugicauda in the Dee estuary. The frequency doubled over the "winter" (July-March) period and this trend was apparently reversed in the summer. The increase in frequency was attributed to selective mortality amongst Non-Yellow animals, caused by exposure to cold brackish water. This was substantiated by a laboratory experiment.

* Present address: Department of Zoology, University College of North Wales, Bangor, Caernarvonshire, U.K. 
The work presented in this paper describes the results of an investigation into seasonal changes in the frequency of Yellow in a Scottish population of the isopod. The frequency of Yellow was much higher than the average in British populations and a preliminary study had shown marked changes in frequency.

\section{Methods}

The estuary studied was that of the River Tyne, East Lothian, Scotland (Map references OS 6 3NT 627787). The population density was high (Heath, 1973) and large samples of isopods (2000-3000) could be easily obtained.

Random samples were taken every $2-4$ weeks, over a period of 3 years from the same $10 \times 10$ yd area of the marsh. Samples, obtained with a long-handled net of a mesh ( $\frac{1}{84}$ inch square) which was impassable to even the smallest specimens, were taken as the incoming tide rose on to the salt marsh. Details of the sampling and scoring procedure are given by Heath (1973).

Water temperature and salinity were also recorded on the sample date and estimations of mean water temperature and mean salinity were made, details of which will be given in another paper. These two variables were chosen for study as they were easy to measure in the field and easy to reproduce in the laboratory. It also seemed likely that there would be considerable seasonal variation in these two factors.

The survival of Yellow and Non-Yellow animals was compared at $10^{\circ} \mathrm{C}$., and $0^{\circ} \mathrm{C}$. in water of low salinity, for reasons which will become apparent when the frequency and environmental data have been presented.

A total of five experiments was conducted at $10^{\circ} \mathrm{C}$., each experiment consisting of two "replicates", A and B, with 50 Yellow and 50 NonYellow animals in each " replicate". The animals in each replicate were kept in $200 \mathrm{ml}$ of water of the desired salinity (obtained by diluting sea water of known salinity), in plastic sandwhich boxes in constant temperature rooms. Four experiments were carried out at $\mathrm{O}^{\circ} \mathrm{C}$. under the same general conditions. More detailed descriptions of the experimental method are given by Heath (1973). The numbers of animals surviving each day were recorded and the mean lengths of life for the two phenotypes calculated. The means were then compared by the Mann-Whitney " U " test (Snedecor and Cochran, 1971).

\section{Results}

\section{(i) Frequency data}

The frequency data for the 3 years: October 1968-October 1969, October 1969-October 1970 and October 1970-September 1971 are presented in fig. 1 , and the full data in table 1.

The data for each year are highly heterogeneous (table 2), although differences between consecutive samples are rarely significant (table 3). The fairly clear minimum in the frequency of Yellow in August/September will not be discussed in this paper as it occurred over the breeding season (July-early October) when a complexity of factors, as yet unresolved might have been acting. All the other data (October-May/June) fell outside the breeding season and any changes in frequency cannot have been due to differences in breeding time or success. This period (October-June) would 
appear to be characterised by a decline in the frequency of Yellow from October to January, followed by a rise in frequency of Yellow from January to June. All 3 years show similarities in the time and magnitude of the changes.

There are no objective criteria for dividing up the data. Bishop (1969) divided the year into the period when the young are distinguishable from the parents (July-March) and the period when the young are indistinguishable from the parents In this work, progeny and parents were not generally scored separately, so this procedure could not be adopted.

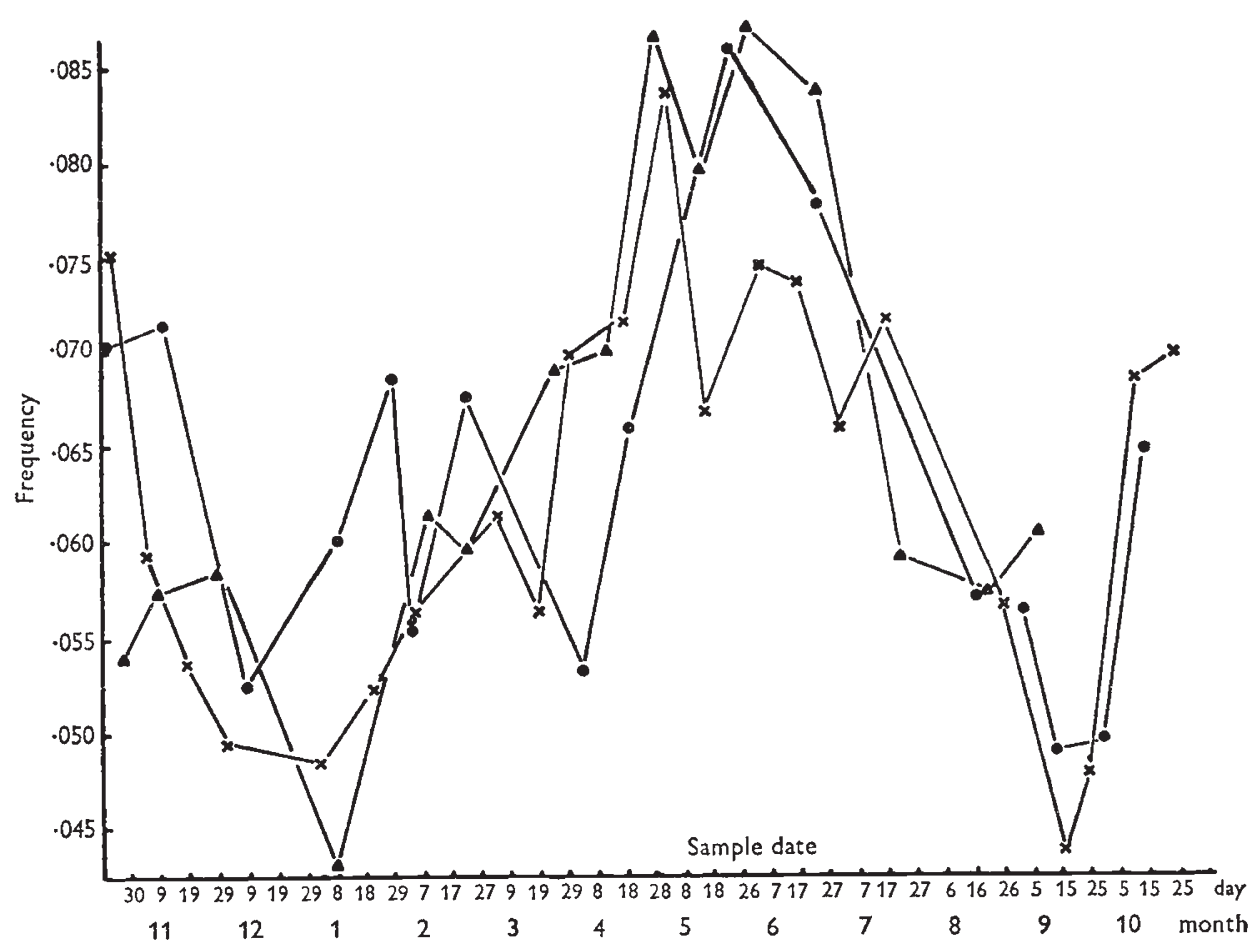

Fig. 1.-Frequency of the Yellow morph against sample date, October 1968-September 1971. $\times-\times, 1969-69 ; \mathbf{O}, 1969-70 ; \mathbf{A}-\mathbf{A}, 1970-71$.

A preliminary analysis of the data was made by combining the frequency data by months and comparing mean monthly frequencies between successive months in 1 year and the same month in different years. The results of this are given in table 4 . They show that the different years tended to have similar mean monthly frequencies and that where they were different, it was often because the changes of frequency occurred at slightly different times. Thus November 1968 had a lower frequency than November 1969 because the frequency declined between October and November in 1968, but there was no decline in frequency in 1969 until November-December. In 1970 there was evidence of a decline in frequency between December-January although the frequency was generally much lower in autumn 1970 than in the corresponding periods in 1968 and 1969. In 1969 and 1970, the decreases failed to be significant. There was, however, fairly good evidence for a 
decline in all 3 years at this time. After January there were no significant increases in frequency between months in 1969, but there was a highly significant rise between April and May in 1970 and a similar rise between

TABLE 1

Numbers and frequencies of Yellow in samples, October 1968-September 1971

\begin{tabular}{|c|c|c|c|c|}
\hline Sample no. & Date & Sample size & No. of Yellow & $\begin{array}{c}\text { Frequency of } \\
\text { Yellow }\end{array}$ \\
\hline 1 & 25.10 .68 & 2118 & 159 & 0.07507 \\
\hline 2 & 4.11 .68 & 1144 & 68 & 0.05944 \\
\hline 3 & 19.11 .68 & 1744 & 94 & 0.05389 \\
\hline 4 & 2.12 .68 & 2559 & 127 & 0.04962 \\
\hline 5 & $5 \cdot 1 \cdot 69$ & 413 & 20 & 0.04840 \\
\hline 6 & 21.1 .69 & 840 & 44 & 0.05230 \\
\hline 7 & 4.2 .69 & 1435 & 81 & 0.05644 \\
\hline 8 & 5.3.69 & 1425 & 88 & 0.06175 \\
\hline 9 & 19.3 .69 & 142 & 8 & 0.05634 \\
\hline 10 & 2.4 .69 & 2112 & 148 & 0.07007 \\
\hline 11 & 17.4 .69 & 2621 & 188 & 0.07173 \\
\hline 12 & 1.5 .69 & 1761 & 148 & 0.08404 \\
\hline 13 & 14.5 .69 & 1596 & 107 & 0.06704 \\
\hline 14 & 31.5 .69 & 2168 & 162 & 0.07472 \\
\hline 15 & 16.6 .69 & 2271 & 168 & 0.07397 \\
\hline 16 & 30.6 .69 & 2015 & 131 & 0.06501 \\
\hline 17 & 16.7 .69 & 1261 & 91 & 0.07216 \\
\hline 18 & 25.8 .69 & 1850 & 105 & 0.05675 \\
\hline 19 & 16.9 .69 & 4343 & 190 & 0.04374 \\
\hline 20 & 24.9 .69 & 854 & 41 & 0.04800 \\
\hline 21 & 9.10 .69 & 1395 & 96 & 0.06881 \\
\hline 22 & 23.10 .69 & 1285 & 90 & 0.07004 \\
\hline 23 & 11.11 .69 & 1635 & 117 & 0.07156 \\
\hline 24 & 10.12 .69 & 1086 & 57 & 0.05248 \\
\hline 25 & 10.1 .70 & 948 & 57 & 0.06012 \\
\hline 26 & 28.1 .70 & 204 & 14 & 0.06862 \\
\hline 27 & 5.2 .70 & 596 & 33 & 0.05536 \\
\hline 28 & 24.2.70 & 2678 & 182 & 0.06796 \\
\hline 29 & 3.4 .70 & 319 & 17 & 0.05329 \\
\hline 30 & 21.4 .70 & 2362 & 156 & 0.06604 \\
\hline 31 & 24.5 .70 & 3447 & 300 & 0.08628 \\
\hline 32 & 23.6 .70 & 2385 & 184 & 0.07715 \\
\hline 33 & 17.8.70 & 1817 & 104 & 0.05723 \\
\hline 34 & 31.8 .70 & 1769 & 100 & 0.05653 \\
\hline 35 & 13.9 .70 & 4508 & 217 & 0.04813 \\
\hline 36 & 29.9.70 & 2468 & 122 & 0.04943 \\
\hline 37 & 12.10 .70 & 2367 & 154 & 0.06506 \\
\hline 38 & 27.10 .70 & 2356 & 127 & 0.05390 \\
\hline 39 & 10.11 .70 & 2971 & 171 & 0.05725 \\
\hline 40 & 1.12 .70 & 888 & 52 & 0.05856 \\
\hline 41 & 8.1.71 & 3889 & 166 & 0.04268 \\
\hline 42 & 9.2 .71 & 3190 & 197 & 0.06175 \\
\hline 43 & 23.2 .71 & 2989 & 179 & 0.05988 \\
\hline 44 & 24.3.71 & 2173 & 150 & $0 \cdot 06902$ \\
\hline 45 & 11.4 .71 & 1775 & 126 & 0.07098 \\
\hline 46 & 26.4 .71 & 633 & 55 & 0.08688 \\
\hline 47 & 11.5 .71 & 1002 & 80 & 0.07984 \\
\hline 48 & 25.5 .71 & 688 & 60 & 0.08720 \\
\hline 49 & 19.6 .71 & 1718 & 144 & 0.08381 \\
\hline 50 & 20.7 .71 & 1174 & 69 & 0.05877 \\
\hline 51 & 18.8 .71 & 889 & 50 & 0.05753 \\
\hline 52 & 7.9 .71 & 2671 & 166 & 0.06214 \\
\hline
\end{tabular}


January and February in 1971. The tendency for the months of May and June to return the highest frequencies, with no significant differences between years, suggests that there may be a true maximum around this time of year.

The initial hypothesis put forward for testing was that there was a decline in frequency during the autumn and a rise in the following months, caused by certain environmental conditions, which will now be considered.

TABLE 2

Overall heterogeneity of the frequency of the Yellow morph within years

\begin{tabular}{lccc} 
& \multicolumn{3}{c}{} \\
\cline { 3 - 4 } & $\overbrace{1968-69}$ & $1969-70$ & $1970-71$ \\
$\chi^{2}$ & $23 \cdot 16$ & $70 \cdot 02$ & 108.43 \\
d.f. & 20 & 15 & 15 \\
$\mathrm{P}$ & $<0.001$ & $<0.001$ & $<0.001$
\end{tabular}

TABLE 3

Successive samples which differ significantly in their frequencies of the Yellow morph

$\begin{array}{cccc}\text { Year } & \text { Samples } & \chi^{2}(1 \text { d.f. }) & P \\ 1968-69 & 18-19 & 4.56 & <0.05 \\ 1969-70 & 30-31 & 7.72 & <0.01 \\ & 32-33 & 6 \cdot 09 & <0.02 \\ 1970-71 & 36-37 & 5 \cdot 19 & <0 \cdot 05 \\ & 41-42 & 12 \cdot 71 & <0.001 \\ & 48-49 & 6.05 & <0.02\end{array}$

\section{(ii) Environmental conditions}

During the October-January period, it was found that estimated mean water temperature lay between about $12^{\circ} \mathrm{C}$. in October and $5^{\circ} \mathrm{C}$. in January, and mean salinity, although usually high in the late summer, fell at some stage in the autumn to around $15 \%$ with minimum salinities below $15 \%$ (Heath, 1973). The stage at which this decline in salinity occurred varied in the 3 years, being in October in 1968, and in December in 1969 and 1970. Thereafter, from January-March, estimated mean water temperatures were below $5^{\circ} \mathrm{C}$., except in 1971 which was particularly mild. Estimated salinities were still around the value of the preceding period. After March, water temperatures rose to around $8^{\circ} \mathrm{C}$. in May and $15^{\circ} \mathrm{C}$. and higher in June and July, whilst estimated salinities also rose slowly, to summer values with the mean above $30 \%$ and minima above $15 \%$ (Heath, 1973).

These conditions were used in designing the experiments since it was apparent that the fall in frequency during the autumn coincided with water temperatures above about $5^{\circ} \mathrm{C}$. and the subsequent rise in frequency perhaps coincided with temperatures below $5^{\circ} \mathrm{C}$. The salinity was generally low over the whole period.

\section{(iii) Results of experiments}

The experimental results are given in table 5, and full data are given by Heath (1973). 
(a) Survival of Yellow and Non-Yellow at $10^{\circ} \mathrm{C}$. (experiments 2/2-4/3)

All the animals were taken from the wild before any decline in the frequency of Yellow was noted. Reference to column 6 will show that in only one case (2/2A) did the mean length of life of Non-Yellow significantly exceed that of Yellow although the difference in 3/3A approached formal

\section{TABLE 4}

Mean monthly frequencies of the Yellow morph. October 1968-September 1971. Figures in brackets ( ) are $\chi^{2}$ values between consecutive months in the same year and between the same months in different years. (Final column compares monthly frequencies in 1970-71 and 1968)

\begin{tabular}{|c|c|c|c|c|c|c|}
\hline & 1968-69 & & $1969-70$ & & $1970-71$ & \\
\hline Oct. & $\begin{array}{c}0.0751 \\
(7 \cdot 019)^{* *}\end{array}$ & $(0 \cdot 488)$ & $\begin{array}{c}0.0694 \\
(0.043)\end{array}$ & $(2 \cdot 674)$ & $\begin{array}{c}0.0595 \\
(0 \cdot 114)\end{array}$ & $(5 \cdot 638)^{*}$ \\
\hline Nov. & $\begin{array}{c}0.0561 \\
(1 \cdot 004)\end{array}$ & $(4 \cdot 051)^{*}$ & $\begin{array}{c}0.0716 \\
(3.653)\end{array}$ & (3.389) & $\begin{array}{c}0.0575 \\
(0.062)\end{array}$ & $(0 \cdot 824)$ \\
\hline Dec. & $\begin{array}{c}0.0496 \\
(0.013)\end{array}$ & $(0 \cdot 077)$ & $\begin{array}{c}0.0525 \\
(0.706)\end{array}$ & $(0 \cdot 238)$ & $\begin{array}{c}0.0586 \\
(3 \cdot 826)\end{array}$ & $(0 \cdot 894)$ \\
\hline Jan. & $\begin{array}{c}0.0511 \\
(0.280)\end{array}$ & $(1.071)$ & $\begin{array}{c}0.0616 \\
(0.167)\end{array}$ & $(6 \cdot 704)^{* *}$ & $\begin{array}{c}0 \cdot 0427 \\
(15 \cdot 111)^{* * *}\end{array}$ & $(1 \cdot 372)$ \\
\hline Feb. & $\begin{array}{c}0.0564 \\
(0.233)\end{array}$ & $(1 \cdot 288)$ & $\begin{array}{c}0.0657 \\
(0.015)\end{array}$ & $(0 \cdot 762)$ & $\begin{array}{c}0.0648 \\
(1 \cdot 685)\end{array}$ & $(0 \cdot 326)$ \\
\hline Mar. & $\begin{array}{c}0.0613 \\
(1.595)\end{array}$ & - & no sample & - & $\begin{array}{c}0.0690 \\
(0.553)\end{array}$ & $(0.771)$ \\
\hline Apr. & $\begin{array}{c}0.0710 \\
(0.689)\end{array}$ & $(1 \cdot 019)$ & $\begin{array}{c}0.0645 \\
(9 \cdot 797)^{* *}\end{array}$ & $(2 \cdot 056)$ & $\begin{array}{c}0.0752 \\
(0.707)\end{array}$ & $(0.354)$ \\
\hline May & $\begin{array}{c}0.0755 \\
(1 \cdot 082)\end{array}$ & $(3 \cdot 254)$ & $\begin{array}{r}0.0863 \\
(1.439)\end{array}$ & $(0 \cdot 131)$ & $\begin{array}{c}0.0828 \\
(0.002)\end{array}$ & $(0 \cdot 885)$ \\
\hline June & $\begin{array}{c}0.0698 \\
(0.053)\end{array}$ & $(1.373)$ & $\begin{array}{c}0.0771 \\
(9 \cdot 347)^{* *}\end{array}$ & $(0 \cdot 516)$ & $\begin{array}{c}0.0838 \\
(6 \cdot 049)^{*}\end{array}$ & $(3 \cdot 343)$ \\
\hline July & $\begin{array}{c}0.0722 \\
(2.760)\end{array}$ & - & no sample & 一 & $\begin{array}{c}0 \cdot 0588 \\
(1 \cdot 226)\end{array}$ & $(1 \cdot 564)$ \\
\hline Aug. & $\begin{array}{c}0 \cdot 0567 \\
(4 \cdot 285)^{*}\end{array}$ & $(0 \cdot 002)$ & $\begin{array}{c}0 \cdot 0569 \\
(3 \cdot 172)\end{array}$ & $(1 \cdot 230)$ & $\begin{array}{c}0.0575 \\
(2.576)\end{array}$ & $(1 \cdot 009)$ \\
\hline Sep. & $\begin{array}{c}0 \cdot 0444 \\
(21 \cdot 466)^{* *}\end{array}$ & $(1 \cdot 056)$ & $\begin{array}{c}0 \cdot 0486 \\
(6 \cdot 453)^{*}\end{array}$ & $(6 \cdot 880) * *$ & 0.0621 & $(11 \cdot 170)^{* * *}$ \\
\hline Oct. & 0.0694 & $(1 \cdot 461)$ & 0.0595 & - & no sample & - \\
\hline
\end{tabular}

Significance levels, $* \mathrm{P}<0.05 ; * * \mathrm{P}<0.01 ; * * * \mathrm{P}<0.001$.

significance. However, in all but two of the eight pairs of means, the mean lengths of life of Yellow are less than those of Non-Yellow. Using Wilcoxon's signed rank test (Snedecor and Cochran, 1971) a value of $\mathrm{T}=4, \mathrm{P}=0.02$ 0.01 is obtained, indicating significantly longer mean lengths of life of NonYellow. The same is true of the median lengths of life, where those of Non-Yellow are greater in six out of the eight cases, $\mathrm{T}=1, \mathrm{P}<0.01$.

(b) Survival of Yellow and Non-Yellow at $0^{\circ} \mathrm{C}$. (experiments 4/3-7/3)

Again there are no significant differences between the mean lengths of life of the two morphs, although in seven out of the eight comparisons, those of Yellow are greater than those of Non-Yellow, $\mathrm{T}=1, \mathrm{P}<0.01$. 
Whilst seven of the eight medians are greater for Yellow than for NonYellow, this is not significant $(\mathrm{T}=6)$, because of the much greater median of Non-Yellow compared to Yellow in 6/2A.

\section{(iv) Re-analysis of frequency data}

It is now possible to divide up the frequency data on the basis of the experimental results. The experimental results predict that over the OctoberJanuary period, when temperatures were in the range $12^{\circ}-5^{\circ} \mathrm{C}$., Yellow

TABLE 5

Experimental results. Survival of Yellow and Non- Yellow at $10^{\circ}$ and $0^{\circ} \mathrm{C}$.

\begin{tabular}{|c|c|c|c|c|c|c|c|c|c|}
\hline \multirow[b]{2}{*}{ Expt. } & \multirow[b]{2}{*}{ Salinity } & \multicolumn{2}{|c|}{$\begin{array}{l}\text { Mean length } \\
\text { of life (days) }\end{array}$} & \multirow[b]{2}{*}{$z$} & \multirow[b]{2}{*}{$\mathbf{P}$} & \multirow[b]{2}{*}{$\mathrm{di}$} & \multicolumn{2}{|c|}{$\begin{array}{l}\text { Median length } \\
\text { of life (days) }\end{array}$} & \multirow[b]{2}{*}{$\mathrm{di}^{*}$} \\
\hline & & $\mathrm{Y}$ & NY & & & & $\mathrm{Y}$ & NY & \\
\hline $10^{\circ} \mathrm{C} .2 / 2 \mathrm{~A}$ & $16 \cdot 00$ & $18 \cdot 20$ & $22 \cdot 40$ & $2 \cdot 337$ & 0.009 & $+4 \cdot 20$ & $18 \cdot 0$ & $22 \cdot 2$ & $+4 \cdot 2$ \\
\hline $2 / 2 \mathrm{~B}$ & $16 \cdot 00$ & $21 \cdot 02$ & $20 \cdot 80$ & $0 \cdot 010$ & $0 \cdot 496$ & -0.22 & $18 \cdot 4$ & $19 \cdot 2$ & +0.8 \\
\hline $2 / 3 \mathrm{~A}$ & 3.20 & $7 \cdot 24$ & 8.96 & 1.599 & 0.060 & $+1 \cdot 72$ & $6 \cdot 0$ & $6 \cdot 8$ & +0.8 \\
\hline $2 / 3 \mathrm{~B}$ & $3 \cdot 20$ & 12.94 & $15 \cdot 24$ & $0 \cdot 177$ & 0.432 & $+2 \cdot 30$ & $7 \cdot 7$ & $8 \cdot 0$ & +0.3 \\
\hline $3 / 3 \mathrm{~A}$ & $2 \cdot 56$ & $6 \cdot 24$ & $8 \cdot 78$ & 1.520 & $0 \cdot 064$ & +2.54 & $4 \cdot 6$ & $5 \cdot 8$ & $+1 \cdot 2$ \\
\hline $3 / 3 \mathrm{~B}$ & $2 \cdot 56$ & $10 \cdot 80$ & $11 \cdot 66$ & 0.441 & 0.330 & +0.86 & $9 \cdot 0$ & $9 \cdot 9$ & +0.9 \\
\hline $3 / 3 \mathrm{~A}$ & $2 \cdot 56$ & $10 \cdot 70$ & $11 \cdot 40$ & $0 \cdot 314$ & $0 \cdot 378$ & +0.70 & $8 \cdot 8$ & $9 \cdot 2$ & +0.4 \\
\hline $3 / 3 \mathrm{~B}$ & $2 \cdot 56$ & $9 \cdot 61$ & $9 \cdot 28$ & 0.720 & $0 \cdot 236$ & -0.33 & $9 \cdot 0$ & $9 \cdot 0$ & $0 \cdot 0$ \\
\hline $4 / 3 \mathrm{~A}$ & $2 \cdot 56$ & $5 \cdot 28$ & $5 \cdot 60$ & $0 \cdot 148$ & 0.444 & +0.32 & $4 \cdot 8$ & $4 \cdot 6$ & -0.2 \\
\hline $4 / 3 \mathrm{~B}$ & $2 \cdot 56$ & $9 \cdot 62$ & 9.96 & 0.810 & 0.209 & $\begin{array}{l}+0.34 \\
\mathrm{~T}=4\end{array}$ & $5 \cdot 0$ & $8 \cdot 0$ & $\begin{array}{l}+3 \cdot 0 \\
\mathrm{~T}=1\end{array}$ \\
\hline & $2 \cdot 56$ & $5 \cdot 30$ & $4 \cdot 30$ & 1.275 & $0 \cdot 102$ & $-1 \cdot 00$ & $4 \cdot 0$ & $3 \cdot 2$ & -0.8 \\
\hline $4 / 3 \mathrm{~B}$ & $2 \cdot 56$ & $6 \cdot 18$ & $6 \cdot 24$ & 0.424 & 0.337 & +0.06 & $5 \cdot 8$ & $5 \cdot \overline{6}$ & -0.2 \\
\hline $6 / 3 \mathrm{~A}$ & $2 \cdot 56$ & $12 \cdot 98$ & $11 \cdot 34$ & $1 \cdot 082$ & 0.140 & -1.64 & $12 \cdot 2$ & $8 \cdot 7$ & $-3 \cdot 5$ \\
\hline $6 / 3 \mathrm{~B}$ & $2 \cdot 56$ & $13 \cdot 12$ & $12 \cdot 22$ & 0.775 & 0.221 & -0.90 & $12 \cdot 4$ & $12 \cdot 2$ & $-0 \cdot 2$ \\
\hline $6 / 2 \mathrm{~A}$ & 12.7 & $18 \cdot 46$ & 18.00 & $0 \cdot 200$ & 0.425 & -0.46 & $15 \cdot 6$ & $16 \cdot 6$ & $+1 \cdot 0$ \\
\hline $6 / 2 \mathrm{~B}$ & 12.7 & 17.96 & $17 \cdot 38$ & 0.872 & 0.192 & -0.58 & $18 \cdot 0$ & $15 \cdot 7$ & $-2 \cdot 3$ \\
\hline $7 / 3 \mathrm{~A}$ & $2 \cdot 56$ & $6 \cdot 10$ & $5 \cdot 38$ & $1 \cdot 261$ & $0 \cdot 104$ & -0.72 & $5 \cdot 0$ & $4 \cdot 7$ & $-0 \cdot 3$ \\
\hline $7 / 3 \mathrm{~B}$ & $2 \cdot 56$ & $7 \cdot 42$ & $6 \cdot 40$ & 0.720 & 0.236 & $\begin{array}{l}-1 \cdot 02 \\
\mathrm{~T}=1\end{array}$ & 4.9 & $4 \cdot 8$ & $\begin{array}{l}-0 \cdot 1 \\
\mathrm{~T}=6\end{array}$ \\
\hline
\end{tabular}

$\mathrm{Y}=$ Yellow; NY $=$ Non-Yellow.

$z=$ Normal deviate $; \mathbf{P}=$ probability level; di $=$ difference in mean length of life; di ${ }^{*}=$ difference in median length of life.

$\mathrm{T}=$ The smaller sum of like signed ranks.

might be expected to decrease in frequency. In the January-March period when temperatures were below $5^{\circ} \mathrm{C}$. Yellow might be expected to increase in frequency. Regression analyses have been carried out by the method of Snedecor and Cochran (1971) and the results are given in table 6 .

Yellow decreased in frequency over the October-January period in the 2 years 1968-69 and 1970-71, although not apparently in 1969-70. This may merely be a failure to detect a decrease because of the generally small sample sizes in this period (see table 1).

Apart from 1971, there is no evidence for a rise in frequency over the January-March period and the reasons for this will be considered in the Discussion. 


\begin{tabular}{|c|c|c|c|c|}
\hline \multicolumn{5}{|c|}{$\begin{array}{c}\text { TABLE } 6 \\
\text { Regression analyses of frequency data }\end{array}$} \\
\hline & & $b$ & $z$ & $\mathbf{P}$ \\
\hline October-January & $\begin{array}{l}1968-69 \\
1969-70 \\
1970-70\end{array}$ & $\begin{array}{l}-0.000261 \\
-0.000127 \\
-0.000233\end{array}$ & $\begin{array}{l}2 \cdot 673 \\
1 \cdot 277 \\
2.712\end{array}$ & $\begin{array}{l}0 \cdot 007 \\
0 \cdot 222\end{array}$ \\
\hline January-March & $\begin{array}{l}1970-71 \\
1969 \\
1970 \\
1971\end{array}$ & $\begin{array}{l}-0.000233 \\
+0.000193 \\
+0 \cdot 000191 \\
+0.000353\end{array}$ & $\begin{array}{l}3.713 \\
1 \cdot 142 \\
0.925 \\
4 \cdot 476\end{array}$ & $\begin{array}{l}0.001 \\
0.254 \\
0.357 \\
0.001\end{array}$ \\
\hline
\end{tabular}

$b=$ Regression coefficient $; z=$ normal deviate; $\mathrm{P}=$ probability level.

\section{Discussion}

There are several possible causes of the observed changes in morph frequency. They are:

1. Systematic errors in scoring.

2. Changes in gene expression with season or age.

3. Differential behaviour of morphs.

4. Natural selection.

The first three possibilities are discussed in detail by Heath (1973) and are considered unlikely to be important.

Selection by physical factors in the environment provides the most acceptable explanation for both the field and laboratory findings. This was the explanation put forward by Bishop (1969) to explain frequency fluctuations in Yellow over the winter. In the population he studied, Yellow was at a low frequency (1.3 per cent) and hence changes in frequency were much less easy to detect. He observed an increase in the frequency of Yellow in the young part of the population over the period July-March, when 2 years' data (1966-67, 1967-68) were treated together. The frequency of Yellow amongst adults did not show any increase in either year, neither did the frequency in the combined young/adult data.

In 1970-71 the young and adults, in my samples, were scored separately and showed an overall increase in the frequency of Yellow amongst the young (from 0.0499 to 0.0717 , chi-squared $=8 \cdot 146$, 1 d.f., $P<0.01$ ), over the July-March period. There is no indication from the data of Bishop (1969) that the decline in frequency during the October-January period and the subsequent rise in frequency noted in this work, occurred. The changes which I observed in my population may, therefore, have occurred in Bishop's population, but not at a readily detectable level.

Bishop (1969) showed that the Yellow morph survived better than the Grey morph at $0^{\circ}-2^{\circ} \mathrm{C}$. in brackish water and the results of my experiments agree with this finding. However, when such low temperatures might have occurred in the Tyne, over the January-March period in 1969 and 1970, there was no rise in the frequency of Yellow (table 6), but in 1971, when temperatures were much higher than in the 2 previous years, an increase in frequency was recorded. Thus, although Yellow survived significantly longer than Non-Yellow at $0^{\circ} \mathrm{C}$. in experimental situations, the difference was not apparently realised in the field, suggesting that perhaps these low temperatures rarely occurred in the Tyne. Instead, it appears that once 
temperatures rose again after March in 1969 and 1970, and after January in 1971, the frequency of Yellow increased. This suggests that some change is occurring in the physiological status of the animals, for it would mean that whereas Yellow animals fared less well than Non-Yellow at $10^{\circ} \mathrm{C}$. in the autumn, Yellow fared better than Non-Yellow at $10^{\circ} \mathrm{C}$. in the spring. The exact basis of this is not yet clear but it is possibly due to differences in growth rate. Yellow animals, although more susceptible to fresh water at $10^{\circ} \mathrm{C}$., may grow more rapidly than Non-Yellow under these conditions, and if large animals survive low salinities better than small animals, the disadvantage of Yellow may be reversed. Evidence for size differences between Yellow and Non-Yellow has been produced (Heath, 1973) as has evidence for enhanced survival of larger animals (Newberry, 1971; Heath, 1973).

In my work, despite these large fluctuations in frequency occurring within each year, the net effect on frequency is very slight. The frequency of Yellow at the start of the breeding season (July) does not differ significantly in the 3 years, neither does the frequency in May in any year differ significantly from that recorded by West (1964) from the same locality (the Tyne) in May 1961, suggesting that there is remarkable stability of frequency.

Little can be deduced as to the mechanism which is maintaining this polymorphism, although several possibilities have been discussed by Heath (1973). West (1964) and Bishop (1969) both found evidence for a deficiency of Yellow progeny in crosses of Yellow $\times$ Yellow animals. Heath (1973) found no significant deviations from either a 2:1 or a 3:1 ratio in crosses of this type. The decrease in frequency of Yellow over the early part of the breeding season (fig. 1) is suggestive or mortality of young Yellow over this period in the wild. The magnitude of this decrease is too large to be attributable to mortality amongst homozygotes which will be rare (if mating is random). The evidence for homozygote lethality is not clear.

It seems most likely that Yellow is maintained in the population by a balance of two or more selective forces as was suggested by Bishop (1969). Such a situation may give rise to an equilibrium when the two selective coefficients are not equal and fluctuate in value (Cook, 1971).

Acknowledgments. $\rightarrow$ I should like to thank Professor B. C. Clarke for suggesting the problem and also for his continued interest and helpful suggestions. My thanks are also due to Professors A. J. Cain and P. M. Sheppard for reading and criticising the manuscript.

This work was carried out at the Department of Zoology, University of Edinburgh.

\section{ReFERENCES}

BISHOP, J. A. 1969. Changes in the genetic constitution of a population of Sphaeroma rugicauda (Crustacea: Isopoda). Evolution, 23, 589-601.

cooк, L. м. 1971. Coefficients of Natural Selection. Hutchinson \& Co., Ltd., London. DOBzHANsKy, тн. 1947. Genetics of natural populations, XIV. Genetics, 35, 288-302.

HEATH, D. J. 1973. Ecological factors affecting gene frequency in a polymorphic isopod, Sphaeroma rugicauda (Leach). Ph.D. thesis, University of Edinburgh.

NEWBERRY, K. 1971. A further study of four morphs of Sphaeroma rugicauda (Crustacea: Isopoda). Unpubl. M.Sc. thesis, University of Liverpool.

SNEDECOR, G. W., AND cochran, w. G. 1971. Statistical Methods. The Iowa State University Press.

STRICKBERGER, M. W., AND wills, c. J. 1966. Monthly frequency changes of Drosophila pseudoobscura third chromosome gene arrangements in a California locality. Evolution, 20, 592-602.

WEST, D. A. 1964. Polymorphism in the isopod Sphaeroma rugicauda. Evolution, 18,671-684. $32 / 3-\mathrm{U} 2$ 